there appears to be some trustworthy evidence that tsetse-flies, including even $G$. morsitans, can exist in numbers where big game is negligible as a food supply.

These wider questions are beyond the scope of Mr. Austen's handbook, which, however, contains a store of information which will be invaluable to those who are seeking to free Africa from the tyranny of these dangerous pests.

G. A. K. M.

THE PSYCHOLOGIST AND THE TEACHER.

The Psychology of Education. By Prof. J. Welton. Pp. $x x i+507$. (London: Macmillan and Co., Ltd., I9Ir.) Price 7s. 6d. net.

WHATEVER criticism Prof. Welton's book may excite, it is undeniably interesting--the most interesting book dealing with its particular problems that has been produced in recent years. With great ability and clearness, the author has drawn a map of life, not as the adult lives it, but as it develops in form and complexity from infancy to manhood. The teacher and the situations with which he deals are in his mind all through. His book is therefore not a treatise on psychology, yet the psychologist's point of view is so dominant that neither does it set forth a theory of education. This Prof. Welton makes clear in his preface. His concern is with the connections between the two-psychology and education-and especially to give a psychological explanation of educational procedure.

The book will surely make a very strong appeal to experienced teachers, for its style is attractive and conspicuously free from abstruse technicalities of expression. Indeed, one is tempted to think that the author has been over-anxious to conciliate the teacher. His opening chapter is particularly addressed to the practical man, who will not fail to note that the psychology which "alone is of worth to the educator" is that "which comes from constant and sympathetic intercourse with children." Although careful reading makes it clear that Prof. Welton means less than he seems to say, it is a mistake, we think, even to seem to imply that all good teachers are willy-nilly good psychologists. There is a distinction between psychological knowledge and a practical acquaintance with psychical relations which comes from experience. The child who uses a brick differently from a ball is not a physicist, nor does social tact constitute a claim to knowledge of psychology. "Every true educator is always making use of real psychology." Is then every true farmer always making use of real chemistry?

The restrictions which the author laid upon himself have led to some difficulties. He very rightly protests against the implicit view of so many child psychologists that children are different from men by reason of their incompleteness.

"Progress is not from a mutilated and incomplete mind to one which possesses all its organs. At every stage of his development, a child's experience is as full and satisfying to him as is that of a philosophical psychologist to himself."

Instead of the serial appearance of new powers to determine the order of which is the main task of the NO. 2 198, VOL. 88] genetic psychologist, his aim should be to show how such development is brought about. All this is admirably put, and as admirably describes the author's object.

In his effort to avoid technical language, however, Prof. Welton has not always been able to achieve satisfying analyses of the processes he describes. In his discussion of the nature of imitation, he restricts the use of the word to what most psychologists call deliberate imitation. This is, of course, giving the word a technical sense, for we call monkeys imitative, though we may deny their intention to imitate. It is no doubt to the writings of M. Tarde that Prof. Welton's protest is due. M. Tarde would find an element of imitation in all that we do, and a tern which includes so much tends to obscure rather than to clarify thought. Our author has a second objection to the current use of the word in psychology. To call an action imitative when there is no intention to imitate is to describe its external rather than its psychical attributes. There is a certain justification for this criticism, but it is doubtful whether Prof. Welton's way out of the difficulty helps very much. He would avoid confusion by including all the nonvolitional forms of imitation under the term assimilation-the general tendency of man to assimilate his mental life to that of his fellows. But how does such a term suit a case like that of Preyer's tiny infant who pursed his lips as he watched his father doing so? Surely this is distinguishable in analysis from catching the enthusiasm of a crowd.

These all-embracing words-assimilation, apperception, \&c.-are a great difficulty in teaching psychology, and for that reason a precise technical terminology cannot be dispensed with. It is as necessary in this subject as in botany, if it is to justify its claim to rank as a science. The whole chapter on the nature of experience is the least convincing in a book which is otherwise extremely readable, and sane to the point of conservatism. No teacher can fail to find much that is helpful in its pages, though he must not expect to get from it an introduction to the methods and results of recent pedagogical inquiry. This Prof. Welton has deliberately left out, except for a gentle gibe at those who use chronoscopes, ergographs, and other terrible machines.

The book is admirably printed, and altogether a valuable addition to English educational literature.

J. A. GREeN.

\section{TIMBER AND PAPER.}

Wood Pulp and its Uses. By C. F. Cross, E. J. Bevan, and R. W. Sindall. With the collaboration of W. N. Bacon. Pp. xi+27o. (London: Constable and Co., Ltd., IgII.) Price $6 s$. net.

"THE present is a Cellulose Age," remark the authors of the book before us. Their statement is not made ad captandum: it will, they urge, survive critical examination.

Perhaps in their epigram there is just a tinge of the spirit which makes every mother's goose a swan; but be that as it may, there is no doubt that cellulose plays a very important part in modern life. In the 